\title{
POVERTY ALLEVIATION AND THE CONTROL OF PUBLIC REVENUE IN NIGERIA: LEGAL AND EQUITABLE ISSUES
}

by Emmanuel Okon*

Introduction

Apart from the dreaded Acquired Immune Deficiency Syndrome (AIDS) now ravaging the world, and particularly the African continent, no other scourge has had such a devastating impact on both the ancient and modern world as the scourge of poverty. According to the World Health Organisation, poverty wields its destructive influence at all stages of human life, from the moment of conception to the grave. It conspires with the most deadly and painful diseases to bring a wretched existence to all who suffer from it. The desire to alleviate, or if possible, eliminate poverty, has engaged the attention of successive governments in Nigeria: Civilian, quasi-civilian ${ }^{1}$ and military administrations. At present the world is still in search of a solution to global poverty, which is why the United Nations currently puts poverty reduction at the top its agenda. ${ }^{2}$ The continual search for ways to achieve poverty alleviation in Nigeria, particularly as it relates to the legal and equitable issues involved, is the topic of this paper.

However, first it is important to define terms so as to make for clarity of thought, better understanding and for consensus ad idem.

* LLD candidate, Faculty of Law, University of Pretoria, South Africa, Lecturer, Faculty of Law, University of Uyo, Nigeria. This paper was first presented by the author at the 38th Annual Law Teacher's Conference held at Lagos State University in April 2002. It has been adapted here to suit this publication.

1 Such as when Nigeria had elected civilian governors in the states and State Assemblies, but with a military 'president' who, along with his cabinet, doubled as law-makers at the national level.

217 October of every year has been declared World Poverty Eradication Day by the United Nations General Assembly. 
Poverty is generally equated with indigence, or, in other words, insufficient resources to sustain a person in life, financial disability or a lack of means of comfortable subsistence so as not to be in want. ${ }^{3}$ It may be argued that 'insufficiency of means' is a relative term. Accordingly, there are two basic types of poverty. One is relative poverty, and the other is absolute or real poverty. My concern here is not with relative poverty, as there is no way this category of poverty can be eradicated. Indeed, such eradication is not even desirable, particularly in a capitalist society like Nigeria because it is an incident of capitalism. As such, one person will always be better or worse off than another. Even among different countries, the comparative conditions of a group, a household or individuals will never be the same. Therefore, not much can be done about this type of poverty. However, even in such cases government can and ought to, as a deliberate public revenue policy, adopt measures to narrow the gap in relative poverty.

Our concern here is with real or absolute poverty. Real or absolute poverty is the absence of basic or fundamental human needs and expectations. Under such a situation, the condition of a group, a household or an individual is below the poverty line. ${ }^{4}$ For this group of people, poverty becomes synonymous with a lack of a future, lack of progress, lack of prospects, lack of development, and the need for poverty alleviation becomes imperative. The right to development is now universally acknowledged as a third generation (human) right. ${ }^{5}$ 'Development' in this sense is itself synonymous with 'modernisation' 6 and embraces both individual and national betterment. It also cuts across the mental, physical, educational, health, social and commercial sectors of national life. Like development, poverty alleviation implies better educational opportunities and an enlightened creative populace, better road networks, and a constant water and electricity supply. Other implications of this concept include gainful employment, better clothing, better food intake and houses. It also involves ownership of automobiles, radio and television

Powers v State, 194 (Kan) 820, 402 P.2d 328, 332.

This is the minimum level of income deemed necessary to achieve an adequate standard of living.

5 RB Seidman The state, law and development (1978) 55. There is admittedly no commonly agreed upon definition of 'development' and the definitions that abound only reflect the intuitive value-sets of their authors.

6 D Seers 'The meaning of development' (1969) 2 International Development Review 2. 
sets and a functional telephone system - a generally better and happier lifestyle. Since freedom from real poverty - or the right to development - is an inalienable human right ${ }^{7}$ it is saddening that the Nigerian government, which is saddled with the responsibility to formulate appropriate national development and poverty alleviation policies, aimed at constant improvement of the well-being of the citizenry, has not done enough towards achieving this goal.

Public revenue is the income received by the government, from taxes, custom and excise duties, franchises or services, and from sale of petroleum products. ${ }^{8}$ Public revenue is often used, or is supposed to be used, for public good: for the provision of infrastructure and those economic goods and services which the government (federal, state or local) dispenses to its citizens. These include good public roads, good public health programmes, good public libraries, good public parks, good education and a better standard of living.

\section{Poverty alleviation measures in Nigeria}

It is generally understood that poverty cannot be eradicated - it can only be alleviated. Even in developed economies of first world countries, like the United States or Britain, we will find a handful of groups who live below the poverty line - pimps, rednecks, Rastafarians, and so on. Nigeria has had many poverty alleviation programmes over the years, none of them a success. Such programmes have been packaged under labels which were as many and as divergent as the type of administration the country has had, and those programmes have always reflected the ethnic background of those who devised them. ${ }^{9}$ For instance, we can vividly recall the 'Operation Feed the Nation' (OFN), embarked upon by the then General Obasanjo's military administration between 1976 and 1979. The object was to make food available for all and thereby reduce hunger and poverty. There was also the Green Revolution of the Alhaji Shehu Shagari civilian administration put in place between 1979 and 1984. The General Babangida military regime came up with poverty alleviating programmes such as the Structural Adjustment Programme (SAP) and the National Directorate of Employment (NDE) Scheme. The Peoples' Bank, Community Bank, Mass Transport Scheme and the Directorate for Economic Reconstruction Programme all formed part of the package. The Directorate for Food, Road and Rural Infrastructure (DFRRI) and the Better Life for Rural Women programme, meant to enhance the welfare of rural women (but which

7 See the Preamble, and arts 2 and 8 of the Declaration on the Rights to Development, adopted by General Assembly Resolution 41/128 of 4 December 1986.

8 Business Dictionary 79, appendix to the New Lexicon Webster's Dictionary of the English Language (1991) Deluxe Encyclopaedic Edition.

9 'Again the challenge of poverty alleviation' Guardian (1 February 2000) 12. 
actually enhanced the welfare of the already rich urban women) cannot be forgotten. General Abacha's regime further evolved the Family Support Programme (FSP) and the Family Economic Advancement Programme (FEAP).

The second Obasanjo administration embarked upon the Poverty Alleviation Programme (PAP). Under this programme, the government earmarked the sum of ten billion Naira for the creation of 200000 jobs in the year 2000. The creation of jobs was reportedly born out of the government's desire to eradicate poverty because the incidence of poverty and unemployment had assumed a dimension that was socially, economically and politically unacceptable. ${ }^{10}$ Government noted that as at the year 2000 , over 60 per cent of the citizens of Nigeria were living below the poverty line. ${ }^{11}$ The government consequently came up with the idea of the National Economic Empowerment and Development Strategy (NEEDS). The due-process procedure in the award of government contracts was the child of this programme.

It is sad, however, that in real terms these poverty alleviation programmes did not create any real jobs, and much of the funds went to cover overheads and into the pockets of government officials - the so-called 'haves' rather than the 'have-nots'. It is also no surprise that the government came up with another poverty eradication programme - NEEDS ${ }^{12}$ - which benefited only the rich. It is the view of this writer that poverty alleviation programmes in Nigeria are often laudable in their conception, but that the fault always lies in the implementation of such programmes. It is submitted that to alleviate poverty, the government has to create real jobs - not just odd jobs or jobs meant only to postpone the evil day.

To create such real jobs, however, government has to diversify the economy as a deliberate policy. It has to encourage private sector participation in development. It has to provide real and qualitative education to its citizenry. In a socially stratified society like Nigeria, a child from a poor family or home can automatically move up the social ladder to being middle-class if he acquires a university education. This is because a higher education can equip him with knowledge thereby guaranteeing him a better job and respect in society.

But this, however, is not the case in Nigeria where education is not of high quality. A situation where the basic laboratory equipment is non-existent in college and university laboratories, and where law

10 Federal Government of Nigeria' 3.

11 Seidman (n 5 above) 55.

12 It is worth noting that NEEDS had the same effect as the Structural Adjustment Programme first introduced by the Babangida regime. 
libraries can neither subscribe to standard journals and basic law reports, nor purchase good textbooks due to gross under-funding, cannot lead to any real or quality education. Quality education is that which equips graduates to fend for themselves, using the knowledge they have acquired. Half-baked graduates are turned out due to the poverty of instructional facilities and the 'education' of these graduates in fact worsened rather than enhanced. The result is that we have graduates who do not have enough confidence to apply their trade or profession, staying idle and looking for white-collar jobs.

It is submitted that 'poverty alleviation' has to be linked directly to government policies, ${ }^{13}$ particularly government's educational policies. There is no way to alleviate poverty in Nigeria without government's policy towards education being reversed. As has been shown above, it is true that Nigeria has had quite a number of programmes aimed at alleviating poverty. So far, all of these programmes have failed. This should convince us that the answer does not lie in abstract programmes; but that, rather, the answer lies in the proper implementation and strict adherence to well-articulated poverty-related government policies.

It remains true that proper education is a very potent escape route out of poverty. Both access to education and freedom from poverty are now matters of international concern, and Nigeria cannot afford to ignore this trend. The United Nations Human Rights Charter recognises poverty as the brutal denial of human rights. This probably is why the outgoing Obasanjo administration embodied the poverty reduction and alleviation programme in its Economic Blueprint for 1999-2003. Under this programme, the poverty alleviation scheme in Nigeria was broken into four phases.

In the first phase emphasis was placed on the education or training of youths who had no education at all, along with school certificate holders, to bring them to school certificate level. This was done under the Capacity Acquisition Programme. Under this programme, youths were sent on a three-month training course to enable them to acquire some skills. Whilst in training, they were paid N3 000.00 per month. ${ }^{14}$

Participants in the poverty alleviation programme in the second phase were university graduates and Higher National Diploma holders. They were attached to industries, organisations and firms under the Mandatory Attachment Programme (MAP). This enabled them to acquire experience in their different fields of study (a tacit admission that their university education was deficient). They were expected to 
set up their own trades, occupations or professions at the completion of their tutelage or attachment.

The third phase in the poverty alleviation programme of the Obasanjo regime was the Rural Infrastructure Development Scheme (RIDS). The intention here was to supply portable water and irrigation to rural areas. Other projects within this scheme included transportation, waterways and jetty development as well as other social welfare projects (SOWEES). The fourth phase was the National Resources Development and Conservation Scheme (NRDCS), which was concerned with the exploration of all mineral resources in the country and the development of water resources. Other projects within this scheme included the protection of the environment from degradation, and the protection of marine as well as aquatic creatures.

Under the micro-credit scheme, 'soft loans' were granted to participants to enable them to purchase equipment in order to set up their trade or profession. It was hoped that this would eventually enable them to employ others and generate a multiplier effect from there. These were all heart-warming expectations and conceptions as earlier stated. However, their implementation left much to be desired. Even in their conception, their emptiness become glaring when compared with well-articulated and honestly implemented poverty alleviation programmes in other countries.

In the United States of America, for instance, the war on poverty was initiated by President Lyndon Johnson in the 1960's through the Economic Opportunity Act of 1964, which created the Office of Economic Opportunity (OEO) to administer the programme. OEO started a number of projects to combat poverty on a broad scale. In addition the Community Action Programme (CAP) provided legal assistance to the poor in dealing with problems such as housing violations, sales agreements and welfare regulations. CAP also assisted impoverished children through pre-school. Impoverished young people were provided with vocational training and remedial education in centres outside slum areas. In collaboration with the Department of Labour and Health Education and Welfare, OEO assisted adults through a number of programmes providing jobs, job training and literacy improvement classes.

In addition, an Unemployment Insurance Scheme was introduced in America in 1935. According to this scheme, qualified workers received cash payments during limited periods of unemployment. These payments were meant to protect the individual worker from complete loss of income whilst unemployed. They also helped prevent unemployment from triggering a loss of income in businesses dependent on purchasing power. Under the Social Security Act of 1935, all states were compelled to introduce compulsory unemployment insurance programmes. Through this, the average 
unemployed worker in the United States receives a weekly payment for a period of 26 weeks during low unemployment periods. During periods of high unemployment, weekly benefit payments are extended. The programme is financed by the federal and state payroll taxes, and is paid for by employers.

Many modern industrial nations have supported and adopted unemployment insurance programmes. In the United Kingdom, for instance, a gradually evolved social welfare and security system was set up in 1948. It provides national insurance, individual injuries insurance and family allowances. The National Insurance Scheme provides citizens with benefits for sickness, unemployment, maternity and widowhood, death grants and so on.

In France, the Social Security Administration controls social insurance, family allowances and workmen's compensation. The law of 1966 made social insurance compulsory in France. In Germany, on the other hand, social insurance services have been in place since 1881. It includes insurance for sickness, accidents, old age and disability, unemployment insurance, workmen's compensation, and so on. The social insurance system is financed entirely by the state.

There are some similarities between the American and Nigerian poverty alleviation programme. However, the Nigerian programme was not tailored to helping adults. Besides, apart probably from phase one (with the Capacity Acquisition Programme), the Nigerian programme is generally still on the drawing board. In any case, the Nigerian programme does not directly tackle the three basic necessities of life: food, clothing and shelter. The idea appears to be that once a person is gainfully employed, he will be able to take care of himself. This is a fundamental misconception, as there is always an alarming number of unemployed, the unemployable and the underemployed. If any progress is to be made in the war against poverty in Nigeria, there must be direct provision for the basic necessities of life.

According to the World Food Organisation, poverty alleviation must start with agriculture, because the poor and undernourished are heavily concentrated in rural areas. This fight must necessarily begin with agriculture and rural development. It is important to note that, in its war against poverty in America, food supplements were offered. Nigeria can do the same. The government must also build houses for the poor instead of engaging in the real estate business for profit in the name of poverty alleviation. How can a man who cannot even feed himself find enough money to purchase a two or three-bedroom flat which costs thousands if not millions of Naira? As we all know, many Nigerians in urban areas sleep under bridges and on roadsides. As for clothing, it is my view that the plight of the poor can be alleviated by providing cheap clothing such as 'aso-oke' fabric or 'ankara'. This 
would not be half as expensive as the warm clothing allowance which is paid to the poor and low income groups in winter in some countries.

What Nigeria lacks is political will, a social focus and honesty of purpose. The so-called 'Nigerian factor' (a euphemism for greed, avarice, nepotism and corruption) has eaten deep into the moral and psychological fabric of Nigerians. One hopes, however, that the adage is indeed true: that every cloud has a silver lining, and that the new administration in Nigeria, headed by President Umaru Yar'Adua, will implement these programmes with greater conviction.

5

\section{Control of public revenue}

It hardly requires saying that public revenue, as earlier defined, has to be prudently controlled and applied if poverty alleviation is to be achieved.

Embezzlement, misappropriation and brazen looting of Nigeria's public revenue by those occupying public or political offices have fast become a way of life. The Corrupt Practices and Other Related Offences Act of 2000 (sometimes referred to as the Anti-Corruption Law), does not appear to have any impact on the endemic corruption in government. Part of the reason for corruption, which is also part of the reason why the poor majority still remains poor, is the overcentralisation of public revenue. The central federal government is super-rich at the expense of the federal states. It is suggested that fiscal federalism would make for poverty alleviation. It would be recalled that fiscal federalism existed under the 1963 Constitution, which allowed the regions to own, control and develop natural resources located in their territories.

By that arrangement, owner and producer-states ceded an agreed percentage of their revenue to the federal government as tax for the maintenance of the common services of the federation. ${ }^{15}$ In that case, the principle of derivation will only be relevant in the sense that the federal government derives revenue from the states and no distribution or allocation back to the states is required. It is submitted that if states are allowed to control the natural resources in their territories, they would better channel the generated funds to poverty remedial needs of the people at the grassroots-level than can be done by the federal government. This is so because it is the individual states which are nearer to the people and are thus better-placed to appreciate the immediate needs of the people. This would aid the monitoring of poverty-alleviation programmes and prevent the overburdening of central government. 
The existing revenue allocation formula completely ignores the environmental, ecological and health effects of oil company activities on the poor indigenes of the oil-producing areas, and this has resulted in hostage-taking and terrorism in the Nigeria Delta area. Water pollution throws the local fishermen into joblessness; land defacement and oil spillage further aggravate the poverty of local farmers. Generally speaking, it is the particular oil-producing states and indigenes thereof who feel the negative, impoverishing effects of crude oil exploration, exploitation and production. These people should not be denied the means to better their lot. Something must be done immediately to alleviate their suffering. It is only when this is done that the word 'justice' would have its proper meaning.

It is particularly sad that the Presidential Committee on the Review of the 1999 Constitution appreciated this injustice in the revenue allocation formula of just 'not less than 13\%' derivation principle or formula in the Constitution, ${ }^{16}$ but then played the ostrich by not making a specific recommendation other than that it should be 'increased substantially beyond the 13 per cent minimum'17 thus beginning another controversy as to what is 'substantial'. Right now, Nigeria's main source of public revenue is oil, and this has been so since the 1970's. Unless there is a major defect in government policy, there is no reason why those who come from areas where the wealth of the nation is derived should be the most poverty-stricken. There is also no reason why the bulk of the country's poorest people should be in, or come from, oil-producing areas - the most naturally endowed areas. It is a cruel paradox that those who live by the seaside are the ones who wash their hands with spittle. There is an urgent need to address and reverse this trend.

\section{$6 \quad$ Legal and equitable issues}

A number of legal, equitable and even politico-legal issues lie in the way of poverty alleviation in Nigeria. Take the issue of population control for instance. It may be argued that over-population is a cause or a consequence of poverty. ${ }^{18}$ It is, however, possible that a controlled population will reduce poverty. It may well be that poor people tend to have more children than they can cater for, and thereby engender greater poverty. But, if this view is correct, it follows that a policy of real job creation will have the dual effect of checking over-population and alleviating poverty. The problem in Nigeria is that population figures are deliberately inflated in some

16 Sec 162(2) of the 1999 Constitution.

17 'Report of the Presidential Committee on the Review of the 1999 Constitution, vol 1' (2001) 44.

18 According to the 2006 census, the population of Nigeria stood at 140 million people. 
areas so as to influence revenue allocation beneficially to such areas. As long as this trend continues, the areas with a truly large population will remain financially cheated and impoverished. The only way of solving this problem is by conducting an accurate and honest census in the country. ${ }^{19}$ Every citizen should be issued with a national identity card to be used for most purposes, including voting during elections. ${ }^{20}$

Still on legal matters, there is a need to enact a statute on poverty alleviation in Nigeria. At present Nigeria has a poverty alleviation policy comprising statements in annual budgets of the federal and state governments without any legal backing. It is instructive that without the Economic Opportunity Act of 1964 in the United States, for instance, the war against poverty in that country could not have gathered the momentum it did.

To alleviate poverty, social security and insurance legislation should be introduced in Nigeria as is done in other countries of the world. To stem the tide of public revenue disappearing into private pockets, ${ }^{21}$ the Corrupt Practices Act must be revisited, ${ }^{22}$ amended and given teeth. It is not enough to know how much public revenue has accrued; public revenue must be equitably distributed and used for the public good. We often hear about petrol subsidies, for instance, and other such subsidies, but nobody feels the effect of these subsidies. Prices of essential goods escalate instead of decreasing. Nigeria should not follow the popular third-world practice of subsidising the rich more than the poor because of their larger consumption and easier access to resources. In a system committed to equity and social justice and the promotion and implementation of the tenets of the International Covenant on Civil and Political Rights and the International Covenant on Economic, Social and Cultural Rights of the United Nations, only those who are unable to pay market prices should be helped.

The best way to help the poor is not by dysfunctional subsidies. It is through substantially increased scholarships, relief payments, guaranteed income and supplements paid out of appropriations made for this purpose by the government that can help the poor. By having control over a portion of income they can call their own, the poor

19 Even the 2006 census figures are controversial.

20 The National Identity Card Project has been a dismal failure too.

21 'Poverty and its brigade' Guardian (25 January 2002) 22: 'Nobody has heard from one Nigerian, and I mean one single Nigerian, to the effect that his or her poverty has been ameliorated. No government official has given a credible account of where the billions for Poverty Alleviation went. It enables some wealthy Nigerians to put away more of the nation's dwindling resources ... perhaps some of them were able to build more houses, get more cars, buy expensive jewellery or fatten their bank account. What we had is otherwise a wealth augmentation (or wealth enhancement) and not Poverty Alleviation.'

The Economic and Financial Crimes Commission (EFCC) has now been set up. 
would be able to make their own choices and be in a better position to take advantage of or create opportunities for income improvements.

There is also the need for land reform. Recently there has been an increased call for the review or abrogation of the Land Use Act of 1978 in Nigeria on the grounds that it is 'unduly oppressive', 'antipeople' and 'undemocratic', and 'directed at depriving the people of the dividends of their God-given resources'. ${ }^{23}$ With the aid of the Land Use Act, the rich have acquired most land in urban areas and cities in Nigeria. The poor have remained rent-paying tenants. It should be stressed that the distribution of land is a major determinant of the distribution of income. Countries that have combined economic growth with an equitable distribution of landholding, such as Japan, Libya, Taiwan, South Korea and Costa Rica, have been able to achieve a relatively more equitable distribution of income, while countries which have allowed the concentration of landholding in a few hands to continue, suffer from a higher incidence of poverty and a more inequitable income distribution. ${ }^{24}$ Right now, the limitation on the extent of individual landholding is observed more in the breach. This is an area that requires close government and legislative attention.

\section{Conclusion}

Issues touching on poverty and public revenue are not only sensitive, they are also controversial. Poverty is highly visible in Nigeria. It is also a matter of common knowledge that Nigeria is a rich country blessed with an abundance of natural and human resources. Yet, Nigerians as a people are one of the poorest and most impoverished in the world. In fact, even foreign governments find the Nigerian situation a paradox, hence their reluctance or unwillingness to write off the country's foreign debts. While the great majority of Nigerians are wallowing in poverty with its attendant consequences, a few others are basking in affluence. The source of their wealth is public funds. Government positions are coveted because they provide a sure source of wealth and thus an escape from poverty and social exclusion.

As this paper has shown, there have been many programmes aimed at poverty alleviation in Nigeria and there has not been a lack of funds. The problem is the absence of good governance, as demonstrated by flagrant corruption, abuse of office and a lack of commitment in prosecuting government programmes. It is my firm 
belief that, if the legal and equitable issues raised herein are attended to, poverty in Nigeria would be a thing of the past. 